\section{Nuclear Genome Diversity and Relationships among Naturally Occurring Buffalograss Genotypes Determined by Sequence-related Amplified Polymorphism Markers}

\author{
O. Gulsen and R.C. Shearman ${ }^{1}$ \\ Department of Agronomy and Horticulture, University of Nebraska, Lincoln, \\ NE 68583
}

\author{
K.P. Vogel \\ U.S. Department of Agriculture, Agricultural research Service, Lincoln, NE \\ 68583-0937
}

\author{
D.J. Lee and P.S. Baenziger \\ Department of Agronomy and Horticulture, University of Nebraska, Lincoln, \\ NE 68583
}

T.M. Heng-Moss

Department of Entomology, University of Nebraska, Lincoln NE 68583

\begin{abstract}
H. Budak
Department of Agronomy and Horticulture, University of Nebraska, Lincoln, NE 68583
\end{abstract}

Additional index words. Buchloe dactyloides, germplasm, phylogeny, polyploidy

\begin{abstract}
Buffalograss [Buchloe dactyloides (Nutt.) Engelm.] has the potential for increased use as a turfgrass species due to its low maintenance and water conservation characteristics. This study was conducted to estimate diversity and relationships among naturally occurring buffalograss genotypes based on the nuclear genome, using sequence-related amplified polymorphism (SRAP) markers. The 56 genotypes studied represented five ploidy levels collected from diverse geographic locations in the North American Great Plains. In addition, blue grama [Bouteloua gracilis (H.B.K.) Lag. Ex Steud.] and perennial ryegrass (Lolium perenne $\mathrm{L}$.) were included as outgroups. Twenty-five combinations of forward and reverse primers were used. Ninety-five intensively amplified markers were scored and used to infer diversity and relationships among the genotypes. All buffalograss genotypes were discriminated from each other with similarity values ranging from 0.70 to 0.95 . Principal component analysis (PCA) suggested that the 56 genotypes could be reduced to 50 due to high similarity levels among some of the genotypes. The distance between buffalograsses, blue grama, and perennial ryegrass were consistent with current taxonomical distances. This research indicates that SRAP markers can be used to estimate genetic diversity and relationships among naturally occurring buffalograss genotypes.
\end{abstract}

Buffalograss is used for home lawns, road sides, golf course roughs, cemeteries, pastures, and rangelands (Beard, 1973). Recently, considerable attention has been given buffalograss as a turfgrass species, due to its drought resistance and low maintenance requirements (Riordan, 1991). Its aggressive stoloniferous growth habit and dense sod-forming characteristic help prevent wind and water soil erosion (Wenger, 1943). Buffalograss is native and found to the

Received for publication 30 Sept. 2004. Accepted for publication 30 Nov. 2004. University of NebraskaLincoln, Agricultural Research Division journal series number 14753 . We wish to acknowledge the United States Golf Association (USGA) and the Nebraska Turfgrass Association (NTA) for their partial support of this research effort.

${ }^{1}$ To whom reprint request should be addressed; e-mail rshearman@unl.edu. shortgrass prairie of NorthAmerica, and is found from Mexico to Canada and from the eastern slope of the Rocky Mountains to the Mississippi River Valley. Buffalograss is mostly dioecious, cross-pollinated, and highly heterogeneous with no evidence of self-pollination ( $\mathrm{Wu}$ and Lin, 1984).

Current knowledge of the genetic basis for buffalograss agronomic traits, and level of diversity and relationships among buffalograss genotypes is limited. Buffalograss is comprised of a morphologically indistinguishable polyploid series, with a base chromosome number of $x=10$, and diploid, tetraploid, pentaploid, and hexaploid plants have been reported (Johnson et al., 1998; Reeder, 1971). Diploids occur only in central Mexico and southeastern Texas, while hexaploids are found growing throughout the Great Plains region (Huff et al., 1993; Johnson et al., 2001), and plants collected in Kansas, Nebraska, and Colorado were hexaploids and tetraploids (Johnson et al., 2001; Reeder, 1971).

Genome evolution in polyploids was recently reviewed (Wendel, 2000). Genes duplicated in ploidy level may retain their original or similar function, undergo diversification in protein function and regulation, or may become silenced through mutational and epigenetic interactions. These changes may affect DNA structure, which allows greater diversity in higher ploidy levels. Hence, gene diversification in polyploids may lead to increased polymorphism detected by molecular markers such as randomly amplified polymorphic DNA(RAPD) markers, simple sequence repeats (SSRs), and restriction fragment-length polymorphisms (RFLPs). Johnson et al. (2001) found higher adaptability in hexaploid buffalograsses, which could be explained by gene diversification as suggested by Wendel (2000).

Molecularmarkers for classification of genotypes are abundant, and unlike morphological markers are not affected by environment (Staub and Serquen, 1996). Molecular markers can be used to identify unique genotypes and associated agronomic traits. Considerable RAPD marker diversity was found among diploid buffalograsses at the inter- and intra-population level (Huff et al., 1993). Recently, sequence-related amplified polymorphism (SRAP) markers were used to assess diversity and relationships among selected buffalograss clones and cultivars (Budak, 2004a, 2004b). Although diversity was reported among selected manipulated clones and cultivars, limited information on naturally occurring buffalograss genotypes is available.

SRAP markers were recognized as a new and usefulmolecularmarker system formapping and gene tagging in Brassica (Li and Quiros, 2001). SRAP markers are polymerase chain-reaction (PCR)-based markers that amplify open reading frames (ORFs) and produce a number of codominant markers per amplification. SRAPs use forward and reverse primers, 17 or 18 nucleotides long, and primers consist of a core sequence of 13 or 14 bases, at the 5', CCGG in the forward primer and AATT in the reverse primer, targeting ORFs in genomic sequences. This core sequence is followed by three selective nucleotides at the 3' end of each primer. SRAP markers are more consistent and repeatable than RAPD markers, and are less labor intensive and time consuming to produce than amplified fragment-length polymorphisms (AFLPs) (Budak et al., 2004b; Li and Quiros, 2001; Welsh and McClelland, 1990). Understanding the genetic structure and germplasm characterization data is essential for efficient plant breeding programs. This study was initiated to estimate genetic diversity and relationships among naturally occurring buffalograss genotypes based on SRAP markers.

\section{Materials and Methods}

Plant materials. Fifty-six buffalograss genotypes and two outgroups, blue grama and perennial ryegrass were evaluated in this study (Table 1). The 56 buffalograsses included 
53 naturally occurring genotypes, 2 selected clones from each of cultivars 'Bowie' and 'Cody' populations, and a vegetative cultivar, 'Density'. The 53 genotypes were diverse in their ploidy level and geographic origin, and were obtained from a plant collection maintained at the University of Nebraska-Lincoln. All genotypes were vegetatively cloned using a single stolon from each population, therefore, each genotype may not represent original population.

Buffalograss genotypes were placed in plant adaptation regions (PARs) developed by Vogel et al. (2005) based on longitudes and latitudes from which the genotypes were sampled (Fig. 1). PARs were developed by overlaying ecoregions (Bailey 1998) and USDAPlant Hardiness Zones (Cathey, 1990). Thermal and moisture

Table 1. Buffalograss germplasm studied, ploidy levels, PARs, and number of bands scored for each genotype.

\begin{tabular}{|c|c|c|c|}
\hline Buffalograsses & Ploidy ${ }^{z}$ & PAR & N. bands ${ }^{x}$ \\
\hline Density & Diploid & Unknown & 29 \\
\hline PX3 5.1 & Triploid ${ }^{\mathrm{y}}$ & Unknown & 30 \\
\hline $45 \mathrm{~B}$ & Tetraploid & 315 & 31 \\
\hline 66 & Tetraploid & 331 & 31 \\
\hline 98 & Tetraploid & 313 & 31 \\
\hline 46 & Tetraploid & 315 & 33 \\
\hline $87 \mathrm{~A}$ & Tetraploid & 315 & $---w$ \\
\hline 119 & Tetraploid & 315 & 31 \\
\hline 143 & Tetraploid & 321 & --- \\
\hline 97 & Tetraploid & 331 & --- \\
\hline 132 & Tetraploid & 321 & 31 \\
\hline 174 & Tetraploid & 321 & 34 \\
\hline 47 & Tetraploid & 315 & --- \\
\hline Prestige & Tetraploid & Maternal parent from Dallas, Texas & --- \\
\hline 378 & Pentaploid & Hebron, Neb. & --- \\
\hline 49 & Pentaploid & 315 & 35 \\
\hline $20 \mathrm{~B}$ & Pentaploid & 331 & 34 \\
\hline 68 & Pentaploid & 331 & 33 \\
\hline 84 & Hexaploid & 315 & 33 \\
\hline $78 \mathrm{C}$ & Hexaploid & 315 & - \\
\hline 70 & Hexaploid & 331 & 33 \\
\hline 2 & Hexaploid & 315 & --- \\
\hline $4 \mathrm{~A}$ & Hexaploid & 315 & --- \\
\hline 83 & Hexaploid & 315 & 35 \\
\hline 188 & Hexaploid & 331 & 34 \\
\hline 170 & Hexaploid & 321 & 31 \\
\hline 77 & Hexaploid & 331 & 34 \\
\hline 209 & Hexaploid & 315 & 38 \\
\hline 126 & Hexaploid & 315 & --- \\
\hline 123 & Hexaploid & 315 & 30 \\
\hline 193 & Hexaploid & 321 & 37 \\
\hline 187 & Hexaploid & 315 & 35 \\
\hline $223 \mathrm{~A}$ & Hexaploid & 255 & 33 \\
\hline 203 & Hexaploid & 331 & 32 \\
\hline 34 & Hexaploid & 331 & 33 \\
\hline $184 \mathrm{~A}$ & Hexaploid & 315 & 33 \\
\hline $153 \mathrm{~B}$ & Hexaploid & 315 & 33 \\
\hline 136 & Hexaploid & 321 & 35 \\
\hline 28 & Hexaploid & 331 & 34 \\
\hline $189 \mathrm{~A}$ & Hexaploid & 331 & --- \\
\hline 89 & Hexaploid & 315 & 32 \\
\hline 178 & Hexaploid & 315 & 35 \\
\hline 152 & Hexaploid & 321 & 31 \\
\hline 17 & Hexaploid & 332 & 33 \\
\hline 234 & Hexaploid & 321 & 31 \\
\hline 196 & Hexaploid & 315 & 34 \\
\hline 240 & Hexaploid & 315 & 31 \\
\hline 7 & Hexaploid & 311 & 32 \\
\hline 137 & Hexaploid & 313 & 32 \\
\hline $32 \mathrm{~B}$ & Hexaploid & 331 & 33 \\
\hline 102 & Hexaploid & 331 & 33 \\
\hline $10 \mathrm{~B}$ & Hexaploid & 315 & 34 \\
\hline $95-55$ & Hexaploid & Nebraska & 33 \\
\hline DP-2F & Hexaploid ${ }^{y}$ & Unknown- & 37 \\
\hline $04-038^{v}$ & Hexaploid & Maternal parents from F. Collins, Colo., and Holdrege, Neb. & 33 \\
\hline $04-046^{\mathrm{u}}$ & Hexaploid & Maternal parents from Ariz., Nebraska and Okla. & 32 \\
\hline Perennial ryegrass & Unknown & Unknown & --- \\
\hline Blue grama & Unknown & Aspermont, Texas (PI 477959) & --- \\
\hline
\end{tabular}

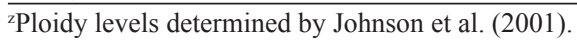

${ }^{y}$ Gulsen et al., unpublished.

${ }^{\mathrm{x}}$ Number of bands scored for each genotype.

${ }^{\mathrm{w}}$ Genotypes with partially missing data.

'A clonal selection from a population of the seeded-type 'Cody'.

"A clonal selection from a population of the seeded-type 'Bowie'.

zones and subzones define conditions for plant growth in a geographical area characterize ecoregions. Plant Hardiness Zones have been developed to classify plants to hardiness or survival zones, which are latitudinal climatic zones modified by nonlatitudinal geographic features.

DNA extraction. Total DNA was extracted from 40 to $50 \mathrm{mg}$ young frozen leaf tissue of individual genotypes, using a DNA extraction kit, Puregene (Gentra Systems, Minn.). DNA concentration was measured with a fluorometer (Hoefer Scientific Ins., San Francisco) and 5 $\mathrm{ng} \cdot \mu \mathrm{L}^{-1}$ DNA templates were made using TE (10 mm Tris-HCl, 0.1 mm EDTA, pH 8.0).

PCR parameters and gel analysis. The 25 combinations of 13 forward and 16 reverse SRAP primers previously evaluated in buffalograsses by Budak et al. (2004a) were used in this study. Each $25 \mu \mathrm{L}$ reaction consisted of $5 \mathrm{pM} \cdot \mu \mathrm{L}^{-1}$ of each of primer pairs, $200 \mu \mathrm{M}$ of each of dNTPs, $2.5 \mu \mathrm{L}$ of $10 \times$ PCR buffer, $5 \mu \mathrm{L}$ of Q Solution, $2 \mathrm{~mm}$ of $\mathrm{MgCl}_{2}$ as a final concentration, $6 \mu \mathrm{L}$ ddH $_{2} \mathrm{O}$, and 1 unit of Taq polymerase (Qiagen, Valencia, Calif.), $25 \mathrm{ng}$ of template. Perkin Elmer Cetus DNAThermal Cycler (Shelton, Conn.) was used and cycling parameters included; one cycle of $2 \mathrm{~min}$ at 94 ${ }^{\circ} \mathrm{C}, 34$ cycles of $1 \mathrm{~min}$ at $94^{\circ} \mathrm{C}, 1 \mathrm{~min}$ at $47^{\circ} \mathrm{C}$, $1 \mathrm{~min}$ at $72^{\circ} \mathrm{C}$, and for extension, one cycle 5 min at $72^{\circ} \mathrm{C}$. PCR products were separated on $2.5 \%$ agarose gel at 90 volt for 5 or $6 \mathrm{~h}$.

Scoring gels and data analyses. Each band was scored as present (1) or absent (0) and data were analyzed with the Numerical Taxonomy Multivariate Analysis System (NTSYS-pc) version 2.1 software package (Exeter Software, Setauket, N.Y.) (Rohlf, 1993). A similarity matrix was constructed based on Dice`s coefficient(Dice, 1945), which considers only one to one matches between two taxa for similarity. The similarity matrix was used to construct a dendogram using the unweighted pair group method arithmetic average (UPGMA) to determine genetic relationships among the germplasm studied. PCA allows easy visualization of the differences among the individuals and determines the optimum number of clusters in a study (Mohammadi and Prasanna, 2003). PCA was performed based on the variance covariance matrix calculated from marker data using PCA. To provide a goodness-of-fit test for the similarity matrix to cluster analysis, first, $\mathrm{COPH}$ module was used to transform the tree matrix to a matrix of ultrametric similarities (a matrix of similarities implied by the cluster analysis) and then, MXCOMP module was used to compare this ultrametric similarities to the similarity matrix produced. In addition, correlations between ploidy level and number of markers scored in each sample were calculated by using SAS Version 8.0 (SAS Institute, Cary, N.C.), PROC CORR. The number of bands was detected based on the observed total number of bands in all genotypes.

The partitioning of molecular variance within and among ploidy levels and PARs was calculated by the AMOVA (Excoffier et al., 1992) in ARLEQUIN ver 2.000 software (Univ. of Geneva, Geneva, Switzerland) (Sch- 


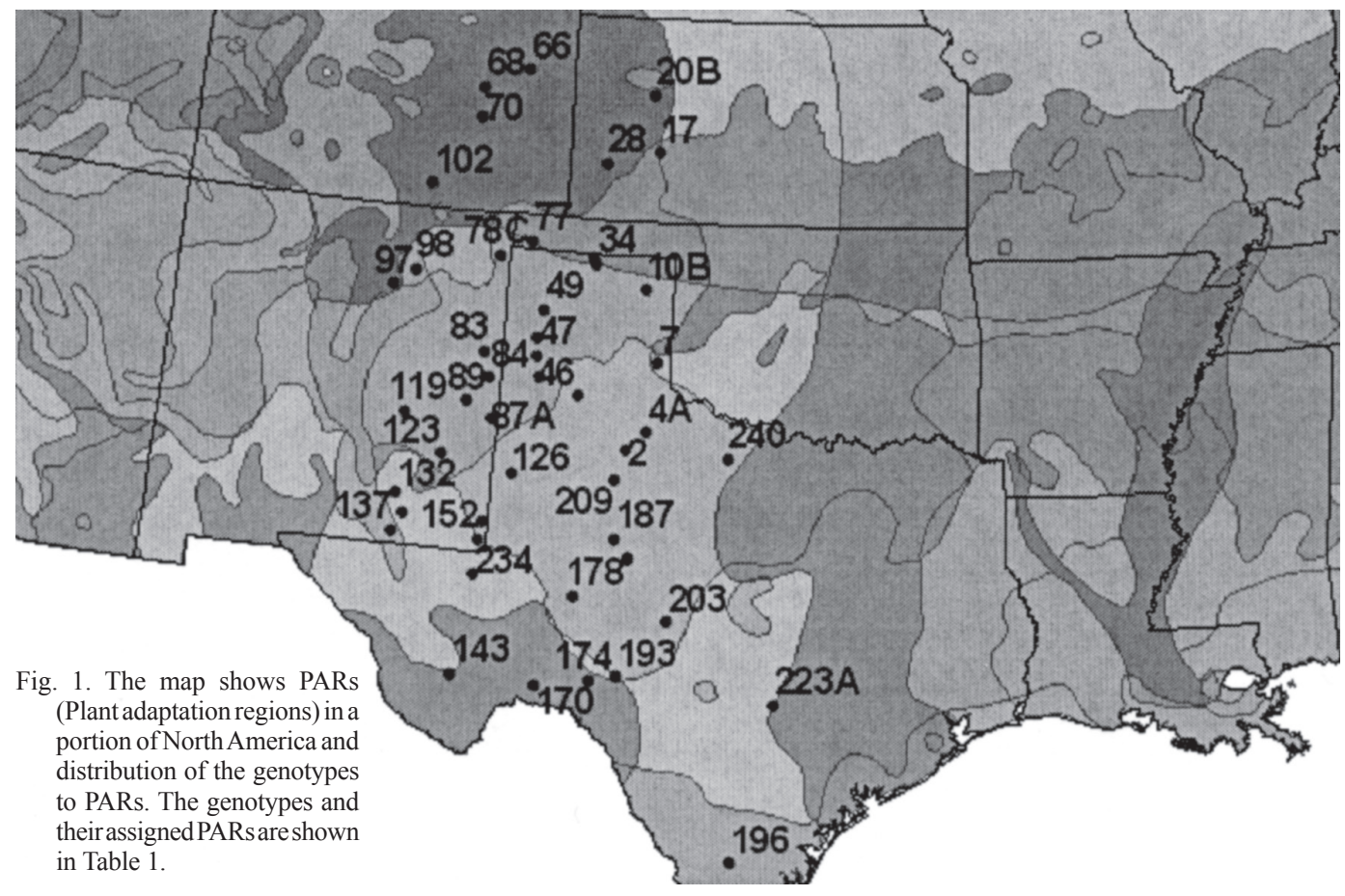

neider etal., 2001). Euclidean distance matrices (total number of polymorphic bands for pair wise comparisons of individuals plants) were used as data input for AMOVA. The number of permutations for significance testing was set at 10000 for all analyses.

\section{Results and Discussion}

In total, 25 combinations of forward and reverse SRAP primers were screened and a total of 95 bands with a high intensity were scored. The number of bands scored per primer ranged from 3 to 17 . The scored markers were comprised of fragment sizes ranging from 110 to 1600 base pairs. The number of markers scored per genotype for the 25 combinations of primers ranged from 29 to 38, and were generally greater at the higher ploidy levels (Table 1). Some variation within a ploidy level may be expected in the observed number of bands due to cross-pollination. For example, the number of bands observed in hexaploids ranged from 31 to 38 , while in tetraploids, they ranged from 31 to 34 . Cophenetic correlation between ultrametric similarities of tree and similarity matrix was found to be high ( $r=0.97, P<0.01)$, suggesting that the cluster analysis (Fig. 2) strongly represents the similarity matrix.

No two buffalograss genotypes were found to be identical as with other cross-pollinating species (Phan, 2000), which agreed with visual observations of the genotypes (Fig. 2). All buffalograss genotypes studied had a similarity levels ranging between 0.70 and 0.95 . This level of similarity was expected.

There were no specific ploidy level grouping patterns. For example, tetraploids, pentaploids, and hexaploids occurred in the same group. Two hexaploid genotypes, 203 and 170, and a tetraploid, 45B, were grouped with a high similarity value, $0.97 \%$. In addition, two other hexaploid genotypes, 34 and 89, were grouped with a tetraploid genotype, 98 . The grouping responses may be due to autoploidy, resulting in higher ploidy levels being derived from duplication of a single genome. Johnson et al. (1998) also hypothesized that autoployploidy occurred in buffalograss. Blue grama and perennial ryegrass, were distinguished from one another with a considerably lower similarity value of nearly 0.29 . As expected, the blue grama genotype used was more closely grouped with buffalograsses than perennial ryegrass, but was still distinguishable from buffalograsses based on SRAP marker determination.

There was a positive correlation between ploidy level and number of bands scored for each genotype $(r=0.48, P<0.05)$ (Table 1). Coupled with broader adaptation zones observed in hexaploids (Johnson et al., 2001), this correlation may infer that extra copies of homologous chromosomes provide new DNA sequences for adaptation to diverse environments as reported by Wendel (2000). This response is the second source of evidence, in addition to ploidy level distribution, demonstrating adaptability of hexaploids throughout the North American Great Plains, especially when compared to diploids, which are more narrowly adapted. Nested AMOVA indicated
Fig. 2. UPGMA dendogram of 56 buffalograsses and two outgroups based on based on analysis of 95 SRAP markers. The last digits indicate ploidy levels of the genotypes.

\section{atad}

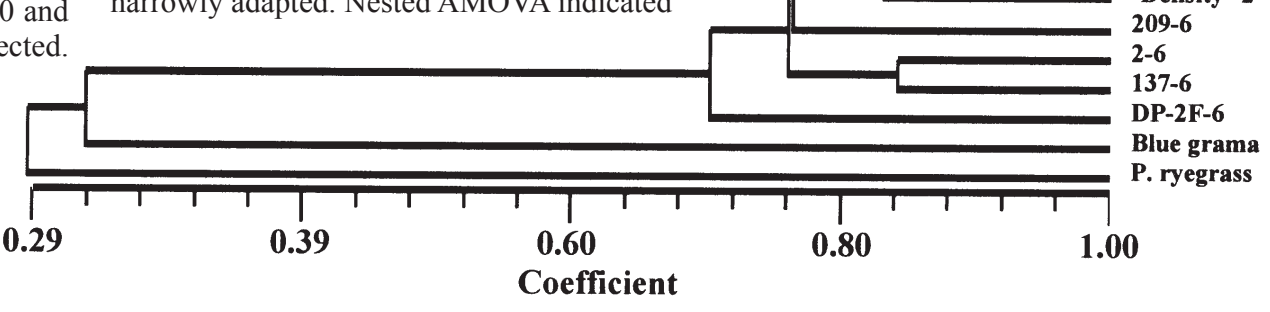




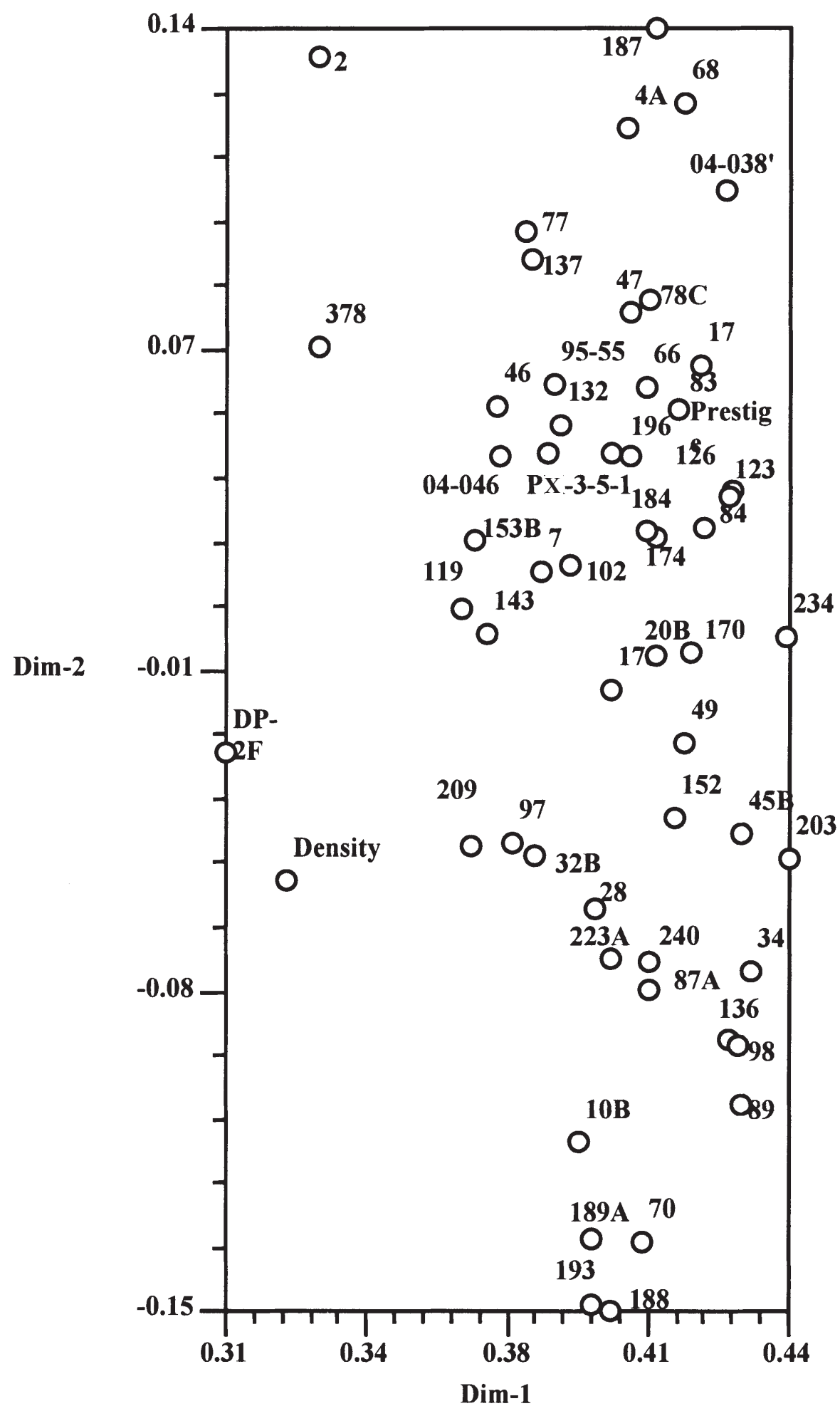

Fig. 3. Relationships among 56 genotypes with different ploidy levels based on principal component analysis (PCA) of SRAP-based genetic similarities.

nonsignificant genetic variation among ploidy levels and PARs (AMOVA not shown). Partitioning of the genetic diversity revealed that almost all of the variation resided within ploidy levels $(98.5 \%)$ and within PARs $(97.5 \%)$. Most likely, diversity among buffalograss populations from different ploidy levels and PARs was equally distributed as a result of the cross-pollination coupled with random herbivore seed dispersal, which played a role in early distribution of buffalograsses (Beetle variation. Based on the results from this study, the genotype number of 56 could be reduced to 50 due to genotype similarity levels based on PCA analysis (Fig. 3). Identifying these similarities will help us efficiently construct a core buffalograss collection and eliminate redundancies.

Based on only one region of cpDNA sequence and one nuclear ribosomal internal transcribed spacer region, Columbus (1999) indicated that some species of Bouteloua were more closely related to other genera than to congeners. He speculated that buffalograss should be reclassified to Bouteloua dactyloides (Nutt.) J.T. The blue grama genotype in this study was quite different from the buffalograsses, with a low similarity value of 0.31 . These results indicate that additional research that includes other related species is needed before taxonomical changes are proposed for buffalograsses.

The SRAP markers efficiently discriminated all naturally occurring buffalograss genotypes in this study. Hence, they may be readily used in establishing germplasm core collections, understanding relationship level, estimating genetic diversity, and integrating markers into genetic linkage maps (Budak et al., 2004a, 2004b). Germplasm organization is of importance for buffalograss breeding programs because of its extensive diversity caused by cross-pollination. Although buffalograsses are known as relatively pest free species, a number of potential pests such as chinch bugs [Blissus occiduus (Hemiptera: Lygaeidae)] (Baxendale et al., 1999) and false smut (Cercospora seminalis Ellis \& Everh.) (Wenger, 1943) have been identified. Initial screening of potential diploid buffalograss parents as convenient ploidy level revealed considerable polymorphism for SRAP markers (Gulsen et al., unpublished). Therefore, the SRAP markers may also have potential in buffalograss breeding programs through marker-assisted selection, which would further enhance buffalograss improvement opportunities.

\section{Literature Cited}

Bailey, R.G. 1998. Ecoregions: The ecosystem geography of the oceans and continents. SpringerVerlag Inc., New York.

Baxendale, F.P., T.M. Heng-Moss, and T.P. Riordan 1999. Blissus occiduus (Hemiptera: Lygaeidae): A chinch bug pest new to buffalograss turf. J. Econ. Entomol. 92:1172-1176.

Beard, J.B. 1973. Turfgrass: Science and culture. Prentice-Hall, Englewood Cliffs, N.J.

Beetle, A.A. 1950. Buffalograss, native of the shortgrass plains. Laramie, Wyo., Univ. Wyo. Agr. Expt. Sta. Bul. 293.

Budak, H., R.C. Shearman, I. Parmaksiz, R.E. Gaussoin, T.P. Riordan, and I. Dweikat. 2004a. Molecular characterization of buffalograss germplasm using sequence-related amplified polymorphism markers. Theor. Applied Genet. 108:328-334.

Budak, H., R. C. Shearman, I. Parmaksiz, and I. Dweikat. 2004b. Comparative analysis of seeded and vegetative buffalograsses based on phylogenetic relationships using ISSR, SSR, RAPD, and SRAP. Theor. Appl. Genet. 1009:280-288.

Cathey, H.M. 1990. USDA plant hardiness zone map. USDA Misc. Publ. 1475. www.usna. 
usda.gov/Hardzone/ushzmap.html. USDA, Wash., D.C.

Columbus, J.T. 1999. An expanded circumscription of Bouteloua (Gramineae: Chloridoideae): new combinations and names. Aliso 18:61-65.

Dice, L.R. 1945. Measures of the amount of ecologic association between species. Ecology 26:297-302.

Excoffier, L., P.E. Smouse, and J.M.Quattro. (1992). Analysis of molecular variance inferred from metric distance among DNA haplotypes: Application to human mitochondrial DNA restriction data. Genetics 131:479-491.

Huff, D.R., R. Peakall, and P.E. Smouse. 1993. RAPD variation within and among natural populations of outcrossing buffalograss [Buchloe dactyloides (Nutt.) Engelm.]. Theor. Appl. Genet. 86:927-934.

Johnson, P.G., T.P. Riordan, and K. Arumuganathan. 1998. Ploidy level determinations in buffalograss clones and populations. Crop Sci. 38:478-482.

Johnson, P.G., K.E. Kenworthy, D.L. Auld, and T.P. Riordan. 2001. Distribution of buffalograss polyploid variation in the southern Great Plains. Crop Sci. 41:909-913.
Li, G. and C.F. Quiros. 2001. Sequence-related amplified polymorphism (SRAP) a new marker system based on a simple PCR reaction: Its application to mapping and gene tagging in Brassica. Theor. Appl. Genet. 103:455-461.

Mohammadi, S.A. and B.M. Prasanna. 2003. Analysis of genetic diversity in crop plants-salient statistical tools and considerations. Crop Sci. 43:1235-1248.

Phan, A.T.P. 2000. Genetic diversity of blue grama (Bouteloua gracilis) and little bluestem (Schizachyrium scoparium) as affected by selection. $\mathrm{PhD}$ thesis. Univ. Manitoba, Winnipeg.

Quinn, J.A., D.P. Mowrey, S.M. Emanuele, and R.D.B. Whalley. 1994. The foliage is the fruit hypothesis: Buchloe dactyloides (Poaceae) and the shortgrass prairie of North America. Amer. J. Bot. 81:1545-1554.

Reeder, J.R. 1971. Notes on Mexican grasses: Miscellaneous chromosome numbers-3. Brittonia 23:105-117.

Riordan, T. 1991. Buffalograss. Grounds Maint. 26:12-14.

Rohlf, F.J. 1993. NTSYS-PC, numerical taxonomy and multivariate analysis system. Version 1.8
Exeter Software, Setauket, N.Y.

Schneider, S., D. Roessli, and L. Excoffier. 2001. Arlequin: A software for population genetics data analysis. Version 2.000. Genetics and Biometry Lab., Dept. Anthropology, Univ. Geneva, Geneva.

Staub, J.E. and F.C. Serquen. 1996. Genetic markers, map construction, and their application in plant breeding. HortSci. 31:729-741.

Vogel, K.P. Vogel, M.R. Schmer, and R.B. Mitchell. 2005. Plant adaptation regions: Ecological and climatic classification of plant materials. Rangeland Ecol. Mgt. (in press).

Welsh, J. and M. McClelland. 1990. Fingerprinting genomes using PCR with arbitrary primers. Nucleic Acids Res. 18:7213-7218.

Wendel, J.W. 2000. Genome Evolution in Polyploids. Plant Mol. Biol. 42:225-249.

Wenger, L.E. 1943. Buffalograss. Kansas State Univ. Agr. Expt. Sta. Bul. 321.

Wu, L. and H. Lin. 1984. Identifying buffalograss [Buchloe dactyloides (Nutt.) Engelm.] cultivar breeding lines using random amplified polymorphic DNA (RAPD) markers. J. Amer. Soc. Hort. Sci. 119:126-130. 